\title{
A Systematic Review of Program Quality in the Field of Positive Youth Development
}

\author{
Jeantyl Norze ${ }^{1, ~ *}$, Melissa Cater ${ }^{2}$ \\ ${ }^{1}$ Biotechnology \& Natural Resources, College of Agriculture, University of Nevada Cooperative Extension, Las Vegas, USA \\ ${ }^{2}$ Department of Agricultural, Extension Education, \& Evaluation, College of Agriculture, Louisiana State University, Baton Rouge, USA
}

\section{Email address:}

jnorze@unr.edu (J. Norze), mcater@agcenter.lsu.edu (M. Cater)

${ }^{*}$ Corresponding author

\section{To cite this article:}

Jeantyl Norze, Melissa Cater. A Systematic Review of Program Quality in the Field of Positive Youth Development. Advances in Sciences and Humanities. Vol. 6, No. 2, 2020, pp. 58-69. doi: 10.11648/j.ash.20200602.12

Received: April 27, 2020; Accepted: May 26, 2020; Published: June 16, 2020

\begin{abstract}
The purpose of the study was to examine areas of competency for quality programming in the field of youth development. Program Quality is one of the new foci of evaluation capacity building (ECB) efforts that has not been clearly defined in the literature. For the purpose of this study, the researchers operationally defined program quality as the program characteristics, indicators, and implementation practice that stakeholders including researchers mutually agree upon. These program quality components are interlinked. It is critical to help youth practitioners think through the logical connection among the components of program quality. This can be partly achieved through professional development, which equips practitioners with competencies necessary to perform their tasks. Implementation of quality is associated with program staff's ability to influence program structure and process. Staff expertise is not defined by only their knowledge and skills but also their ability to respond to challenges and problems they face daily at work. Through a systematic literature review, the authors identified key areas where program quality in the field of youth development can be effectively impacted by staff training activities; these areas then served as the components of a proposed staff training model. The latter consists of four components: child/youth development, social ecological theory, program management, and program theory. These components were found to be critical for quality programming.
\end{abstract}

Keywords: Program Evaluation, Staff Training Model, Positive Youth Development (PYD), Program Implementation, Program Theory, Program Quality

\section{Introduction}

\subsection{What Is Program Quality}

Program quality is one of the new foci of evaluation capacity building (ECB) efforts. The focus on the logic model and program outcomes without attention to program quality has produced scant evidence of better evaluation practices $[1,2]$. Therefore, the attention of ECB efforts has geared towards program quality. This change is supported by evidence that program staff who engage in program quality assessments achieve greater program effectiveness, and ultimately better program outcomes [3]. The discussion of program quality is, however, hindered by the fact that it is not clearly defined in the literature $[4,5]$. A clear definition is needed to allow discussion of program quality and its beneficiaries. For the purpose of this paper, program quality is defined as key program characteristics that program stakeholders (both internal and external) and researchers agree are critical to program success. According to Skaff et al., practitioners and scientists need to empower community leaders and stakeholders to be involved in the design of evidence-based programs [6]. Quality must be defined through the process involving a dialogue among the stakeholders included in programming [4].

Program quality is inherently context specific. Thus, it must meet the specific needs of a target population [7, 8], fit the environment [9], and support the specific goals of the program itself [10]. Socially constructed needs are culturally relative and, therefore, should be determined by the context and culture [11]. This makes it hard to generalize program quality from one program to the next although there are some 
mutually agreed upon criteria within the literature that seem to be universal. For instance, the basic needs including physical safety, psycho-social, exploration, and discovery needs are universal and represent the contribution of researchers about the understanding of child and youth's growth and development [12]. The basic needs must be part of the setting standards regardless of the environment in which a program operates. As a result, a quality program must meet the basic needs and the social constructed needs of young people [12].

Researchers have argued that program quality goes beyond the identification of program quality features, and that there is a need to fully understand how to successfully implement these features [13]. Thus, mutually identified program characteristics and indicators of program quality must be supported with implementation practices that lead to quality. Program staff should pay attention to what the program is doing and how program activities contribute to the program's theory to ensure program quality [14]. Implementation of quality is associated with program staff's ability to influence program structure and process [15]. Knowledgeable and well-trained staff are among the key predictors of sustainable program quality [16]. Staff training has been identified as one avenue that improves staff members' understanding of program quality and experience in implementing quality practices [17].

\subsection{General Definition of Staff Training}

Staff training is a process by which employees acquire the necessary skills and knowledge to perform a task or job better [18]. Staff training is designed to enhance short-term and/or long-term job performance of employees [19]. As a result, employees become more proficient to produce more and/or higher quality work. They become qualified to work in positions of greater challenges and responsibilities [20]. Staff training is required for employees to systematically develop their knowledge, skills, and attitudes in order to meet program expectations [21]. Moreover, staff training not only provides the skills and knowledge to improve job performance, but also aligns employees' behaviors and attitudes with the vision, goals, and objectives of the program or organization [20]. Staff training is based on the premise that the development of competences - knowledge, skills, and attitudes - is necessary for organizations to grow $[21,22]$ and/or to meet programs outcomes. Staff training is a process that should be planned and continuous [23]. The training activities should be carefully designed with the purpose of influencing the individual employees' job performance or tasks [24]. In brief, staff training enhances staff quality, which is a critical component that leads to high-quality programming [25]. As a result, many researchers and staff, themselves, have called for training for those working with youth.

\subsection{General Impacts of Staff Training}

Staff training is necessary to reinforce youth workers' knowledge of theories, the rationale of programs [26], and youth developmental needs [27]. Otherwise, youth workers may lack sound knowledge grounded in theories, research, and best practices. Staff training can create a common understanding of youth development [27], which aims at meeting youth developmental needs and building competencies to enable them to transition successfully to adulthood [28]. For instance, Weissberg and O'Brien found that staff training improves youth professionals' knowledge about 4-H youth development programs [29]. Additionally, staff training equips professionals with varying skills-management skills, communication skills, listening skills and leadership skills--that are necessary to meet the divergent needs of youth [30] and sustain the quality of a program implementation [29].

Staff expertise is not defined by only their knowledge and skills but also their ability to respond to challenges and problems they face at work [31,32]. Many youth workers struggle to handle youth with antecedents of violent behavior [13] and issues related to race [33]. As a result, staff members need to gain knowledge of the dilemmas of youth work [34], which have been classified into categories and subcategories [13].

Staff training exposes youth workers to best practices to reduce barriers to achieving outcomes [35-38]. Some of the youth development best practices consist of considering age, developmental stage, and cultural appropriateness when designing programs [39]. The same authors further argue that practitioners should be able to support and provide youth with opportunities for physical and psychological safety, relationship building, community involvement, and skill building. Staff training helps youth workers understand and assess programs in terms of the keys to quality youth programs. Research has shown that most assessments of program quality include measures such as relationships, environment, engagement, social norms, skill-building opportunities, and structure [40]. In addition, quality positive youth development programs, according to Eccles and Gootman, are associated with the following factors: climate safety; appropriate structure; supportive relationships; opportunities to belong; positive social norms; support for efficacy and mattering; opportunities for skill building; and integration of family, school, and community efforts [41].

Staff training helps youth workers engage youth as partners and develop activities that meet their developmental needs and interests. Youth workers need to learn how to design and implement learning activities that give rise to close bonds with the staff members. Research has documented youth-adult relationships as a key factor for youth retention and success in positive youth development programs [42]. As can be seen, staff training has been a determinant used to equip youth workers with the necessary competency to achieve high levels of implementation, which is crucial to achieving program outcomes [43].

In an era of increasing needs and limited resources, staff training can serve as a platform where youth workers build networks to share and discuss work related information and 
find solutions to implementation inconsistencies [30]. For instance, staff training can serve as a platform to discuss barriers to youth development practice such as time limits of programs, lack of resources, policies, directives, work overload, and so forth. Staff training can be a powerful platform to solve complex problems.

In addition, staff training helps youth workers understand program logic by building connections among program assumptions, resources, activities, and desired program outcomes. It helps youth workers understand the testable mechanisms that explain why program outcomes are achieved. This competency is critical to achieve and sustain program quality (5).

Further, staff training helps identify challenges of overcoming staff resistance to change [39]. Changing has always been hard. As a result, many practitioners continue to use approaches with youth that have little or no evidence of effectiveness and are often very harmful to the society [44, 45]. The youth development approach is an evidence-based approach that demands time and effort, which makes it hard to embrace [39]. Staff training is an avenue to foster change and adoption.

Positive Youth Development (PYD) is a paradigm shift from other youth service fields that focus on youth assets or strengths instead of problems [46, 47]. Many youth workers have little background in positive youth development [30]. Additionally, many youth staff enter the field without specific job training [48]. They often rely on their prior experiences, which are unrelated to work with children [49]. Because youth staff are the frontline workers, it is necessary for them to understand the philosophy and core components of positive youth development [27]. They have the potential to influence positively young people's academic, social, and emotional achievements as well as their career choice and self-portrait [30]. Staff training improves youth staff's selfconfidence [50]. According to Bowie and Bronte-Tinkew, youth staff possess a unique characteristic - "sigfluence: a positive, significant, long-term interpersonal influence over youth" - that can be developed through trainings as they help young people transition successfully to adulthood [30, p. 2].

Programs can no longer afford to rely only on youth staff's best instincts and prior experiences to promote healthy, thriving young people [51]. Over time, the course of inexperienced and untrained youth staff can negatively influence the competency level, strength, and effectiveness of a program [52]. Limited or inadequate staff training may affect youth staff's competency and confidence to implement program components effectively, which in turn may lead to burnout [53].

Research has shown that staff training is one of the key elements in the overall effectiveness of a program's ability to promote positive youth development [54-56]. Youth staff who receive training are reported to have higher levels of competency [27, 57] and feel more relatable and more confident to work with youth [57].

Despite the importance of staff training for program outcomes, little research has studied the link between staff training and program quality. Among the few who investigated this relationship, two scholars found it to be significant $[58,59]$. To sum-up, staff training equips youth staff with knowledge of relevant theory and research regarding youth's physical, emotional, social, and cognitive development; risk and protective factors; and principles of adolescent development.

\subsection{Core Components of Positive Youth Development Program Trainings}

Staff training can help youth workers who are from different educational backgrounds to have a common understanding of the core principles and practices of positive youth development [49]. Having the ability to support youth development while simultaneously acting as partners to youth still remains a challenge for youth staff [60]. According to Huebner et al, youth staff should be able to understand and articulate the content of youth development work and deliver it appropriately where youth are engaged and interactive while experiencing developmental and learning growth [27].

Positive youth development consists of an array of activities, practices, mandates, and aspirations that are both confusing and promising [27]. The identification of core competencies is the first step toward creating a well-trained workforce to deliver quality programs [61]. Core competencies are the required knowledge, skills, and attitudes necessary for youth staff to produce and deliver high quality programming [48]. Core competencies can be used as practice standards for youth staff and a guide for staff training efforts with the perspective to provide high quality youth programming $[61,62]$. They can serve as a guide to design training for youth staff [54]. However, establishing core competencies for such a diverse youth-service field is challenging.

A review of 14 field-based competency frameworks on content, structure, and usage in system-level initiatives resulted in considerable agreement in terms of the content [62]. Vance's work found substantial agreement on the following contents: Child/youth development, positive guidance, families and communities, program management, professionalism, and communication [48]. According to Vance's study, a substantial agreement occurs when at least 80 percent of the considered frameworks included a particular competency area. As can be seen, there is common understanding that youth staff should understand the principles of child and youth development and be able to implement them at the program level. Second, they should use positive guidance to manage youth's conduct. Third, they should build relationships with communities and organizations that support youth programs. Fourth, they should demonstrate management skills such as time management and resourcefulness when implementing a program. Finally, they should show professionalism by following the program rules and committing to professional growth. In addition, many youth workers acknowledge their priority needs for training in experiential learning methods 
and child \& adolescent development [63].

The National Collaborative on Workforce and Disabilities (NCWD) for youth synthesized the competencies of youth service professionals in 10 competency areas: knowledge of the field, communication with youth, assessment and individualized planning, relationship to family and community, workforce preparation, career exploration, relationships with employers and between employer and employee, connection to resources, program design and delivery, and administrative skills [64].

In addition, Fordney and Jones suggested the following recommendations for positive youth development training programs [65]. First, staff training for youth staff should consist of information on the characteristics of effective teachers, effective communication skills, and how to create learning opportunities and activities for youth to develop cognitive, social, and emotional skills. Second, youth staff should understand they have a greater role in the youth lives they serve than just lecturing and learn how to be a positive role model for them. Third, they need to understand that facilitators who appreciate life are more effective in impacting people's lives.

Additionally, staff training should focus on motivating the potential implementers, youth staff members. Although the implementers' motivation is essential to youth learning [66], this important objective is usually missing from most programs [67]. Few program trainings include trainees' motivation as part of their objectives [68].

Moreover, self-efficacy could be an important program training goal because implementers with high self-efficacy are more confident in implementing innovative lesson plans [69]. According to Turner et al., high self-efficacy is associated with implementation [70]. Therefore, attention should be given to practitioners' sense of competency for facilitating quality implementation.

Further, reflection should be encouraged among implementers. Since positive youth development programs emphasize the importance for youth to acquire self-reflection skills, it is necessary for youth workers to have the opportunity to understand and practice these skills. Although research has found that implementers who have strong selfreflection are able to integrate theory into practice [71, 72], few program trainings incorporate self-reflection in their curriculum $[65,73]$. It is important to provide staff with opportunities for skill demonstration, modeling, and feedback as well. Youth workers need to be able to express their opinions, challenge existing assumptions, and develop a shared language and understanding of development [74].

Staff training should involve activities that can equip youth staff members with best contemporary instructional strategies to deliver educational contents [75]. Educators' teaching style should promote active, youth-centered learning [76]. They need to have the ability to shape the learning environment in such a way that it promotes engagement, participation, understanding, creativity, and critical thinking. The use of technologies can enable educators to reshape the learning environment in which learners engage in a complex and rich network of resources and information [76].

Helping youth workers to attend advanced trainings, which reflect the culture and experience of youth in a community, can strengthen the development of youth program staff [77], and further increase the quality of instruction for the potential youth development practitioners. According to Smith et al., educational organizations should focus on high-quality instruction [3].

An interagency collaboration between local colleges, universities and organizations or programs can enhance quality and credibility in the positive youth development field [78] by developing jointly an agreed upon, standardized youth development curriculum. A similar interagency partnership can also pool resources to train youth workers [79]. Some researchers suggest that there is a need to standardize the common practices in the field [27]. By building a network of experts for staff training, youth development professionals taking a critical step toward creating a well-trained workforce to deliver program quality with effective youth development practices [80]. The most influential youth programs are based on a developmental framework that uses trained staff, provides appropriate structures, and encourages supportive relationships [41]. Overall, deliberated programming and well-trained staff are critical to support and provide children and youth with opportunities to grow intellectually, socially, emotionally, and civically or morally.

The purpose of the study was to examine the intersection of staff training and program quality in the field of youth development. The following research questions guided the study:

1. How is program quality defined in the youth development literature?

2. How is staff training described in the youth development literature?

3. How is program quality and staff training addressed in the positive youth development literature?

\section{Method}

This was a systematic review of literature in the positive youth development field. The systematic literature review method was used because it provided a high-level overview of high quality, relevant, evidence-based research in youth development, which were identified, selected, and appraised using the following criteria [81].

\subsection{Eligibility Criteria}

The researchers reviewed relevant articles in youth development specifically those on positive youth development that addressed staff training and program quality. Articles that included "youth development" and "staff training" and "evaluation" were examined to determine if they addressed program quality measures such as youth participation, youth engagement, adult-youth relationships, appropriate structure, fidelity, and alike. Peer reviewed and non-peer reviewed articles were considered with the purpose 
of capturing as much relevant available information as possible in the study. These articles address most importantly program structures and program process that lead to successful implementation. Articles that focused on preventing youth's problems were excluded.

The researchers included in the study afterschool and community-based interventions that support staff training. In addition, training implementation and evaluation interventions that identify and promote youth development practices that lead to program quality were included.

All designs including, but not limited to, research survey designs and pre-post designs-empirical designs, and theoretical designs were considered in the study aiming at including as many available relevant studies as possible. Non-randomized designs were included because they are more common in the field. The article search was conducted in English. Only articles that were written in English were included in the study.

\subsection{Search Strategy}

The articles included in the study were searched in Google scholar. Additionally, the Journal of Extension, the American Journal of Community Psychology, the Journal of Youth Development, and PubMed Journals were included in the search because of their overall focus on youth development. Their publication years included those dated from 19702016. The researchers used the following key words for the search: "staff training in youth development," "program implementation," "program quality and positive youth development", and "core competencies for youth workers." In addition, useful articles from the reference lists of the selected studies were also included. The titles and the abstracts of all searched articles were examined for relevance before their inclusion in the study. Overall, 207 articles were searched, but only $124(59.90 \%)$ met the eligibility criteria.

\section{Results}

\subsection{Staff Training as Factor of Program Quality}

This study found that staff training is a well-researched area. However, little research has focused on the relationships between staff training and program quality [27]. Among the few studies that researched the association between staff training and program quality, two found them to be correlated $[41,59]$.

In addition, research has shown a lack of consensus about the core competencies that youth workers should possess in order to fulfil their duties properly. Therefore, three core components were chosen by the researchers, among the research finding lists that were believed to have a greater impact on program quality implementation. These core components: program management, child/youth development, and program theory, should enable youth workers to establish logical connections between program structures and program processes, which are essential for program quality.
These three core components convey an integrated information base about program processes (fidelity, adaptation, and participation) and program structures (group size, staffing structure, physical environment). For instance, the core component "program management" provides youth workers with solid knowledge in youth participation, implementation fidelity, and regulation of youth-external systems interactions. Whereas, program theory prepares them on implementation fidelity and adaptation. The core component "child/youth development" provides youth workers a foundation in youth participation, implementation adaptation, program structure, and youth-external system (family and community). As can be seen, in most cases the learning outcomes are similar and, therefore, overlapped. As a result, the contents that were believed to have stronger ties with core components were development activities. For instance, program management includes youth participation, program theory includes fidelity and adaptation, and finally child/youth development includes program structures and youth-external system interactions.

However, to make the model more comprehensive, the researchers unfold the youth-external systems interactions component separately from child/youth development and program management through the lens of the social ecological theory, which has increased the number of competencies in the staff training model to four components. The first component of the staff training model is program management.

\subsection{Program Management}

Program management is essential to ensure quality participation. It involves mutuality planning and teaching, which build a trustworthy learning environment favorable to youth participation, which in turn is necessary for learning and growth. A key outcome of an effective program management is youth participation.

Youth Participation

Youth participation is a multifaceted variable, but with no consensus about its dimensionality [82]. This multidimensional concept implies active engagement in a program. According to Lerner et al., it is the contribution of youths to their surrounding world [83]. The most contemporaneous measurement of the youth participation dimension includes dosage, duration, breadth, intensity, and consistency [82].

Research has reported participation as an important variable of youth development program quality [10]. Youth gain more from participation when their learning experiences extend over time in terms of intensity, duration, and breadth [84]. However, youth participation requires a safe haven, fun activities, and mutuality in teaching and learning to occur.

Research has shown that staff members with strong behavioral management skills provide a safe environment conducive to development of peer and youth-adult relationships [85]. Youths who develop positive relationships with adults are more engaged and less likely to drop out [85]. In addition, a physically and psychological safe environment 
increases youth learning and participation [86]. According to McLaughlin, adolescents should spend their time in a way that fosters learning and social development [87].

Research suggests that fun and challenging educational activities attract youths [85]. Fun and challenging activities facilitate peer relationship development and learning whereas boring activities inhibit participation and learning [88]. Therefore, learning methods and activities that foster voluntary participation are encouraged. In addition, learning methods that tailor youths' learning styles and offer opportunities for skill-building are encouraged since recreational and skill-building activities are attractive to young people [85, 87]. Further, well-delivered intervention fosters enthusiasm and commitment in participants [89].

Further, mutuality in teaching and learning is critical for youth participation. Therefore, staff members need to work together with youths as partners. Setting norms together with youths is ideal to help them know in advance how to interact, share, learn, and grow together. According to Larson and Walker, sharing norms, expectations, and limits with youths on acceptable conduct creates a predictable, secure environment for healthy development of adolescents [13]. Youths are more likely to commit to guidelines issued from collaborative work with staff [90].

\subsection{Program Theory}

The second component of the staff training model is program theory. Program theory is the mechanism by which program interventions are conceived to achieve the desired outcomes [91, p. 209]. According to Weiss, program theory is also the connections between the program assumptions and what actually occurs at "each small step along the way" [92, p. 35]. There is an emergent need to help staff think through these connections [93]. Program Theory is an avenue that fosters program adoption and implementation with fidelity.

\subsubsection{Fidelity}

Fidelity is a multidimensional variable of program quality, which can be measured in terms of adherence, dosage, quality of delivery, participants' responsiveness, and program differentiation [94]. A comprehensive picture of fidelity can only be captured by using all the dimensions [95]. Other researchers argue that fidelity can simply be measured by either adherence, dosage, or quality of delivery [96]. According to Fagan et al., it is an imperative to deliver programs as planned in terms of dosage, integrity, and responsiveness [88].

For this review, program differentiation, which is according to [94], the identification of unique features and core components of programs, fits well with the purpose of this article. Core components can be determined by surveying program designers and/or conducting component analysis, which helps to know which components have the most impact [94]. Detailed information about core components are necessary to avoid drifting away from what was originally planned and to facilitate the evaluation [97,
98]. The deviation from implementation fidelity is a major concern [94, 99]. It becomes difficult to assess the theory behind the importance of core components of a program if they are not implemented with fidelity [100]. In essence, for implementation to be effective, it needs to be congruent with theory, content, and methods of delivery.

\subsubsection{Adaptation}

Another aspect of program theory is adaptation. Adaptation can be necessary to meet changes in developmental needs and interests despite the fact it conflicts with fidelity. Youth development programs must be developmentally appropriate and/or stage-environment fit [101]. In addition, fidelity can sometimes conflict with youths' increased desire for independence and choice [85]. However, adaptation needs to be aligned with the rationale of a program and carefully assessed during the implementation [102]. Adaptation must preserve the core components of a program in order to achieve the intended outcomes [102]. In other terms, adaptation should be theory driven. In addition, adaptation may fail if the theory is not sound or valid [103]. Similarly, lack of quality of adaptation leads to implementation failures [100]. Therefore, science-based strategies must be used to regulate adaptation to prevent decrements in program effectiveness [104].

However, adaptation can happen by inserting additional components to the original program and/or implementing the original components differently from previously prescribed [105]. The additive adaptation has been reported to associate with program effectiveness and often happens in conditions of high fidelity [106].

\subsection{Child/Youth Development}

Another component of in the staff training model is child and youth Development. Child/youth development provides youth workers with insights about positive youth development, which is a strength-based approach of child/youth development. The latter is based on the principle that children/youth participation stimulates growth and development. In addition, youth establish mutual relationships with their surrounding world. However, these relationships need to be mutually beneficial for growth to occur. Therefore, children and youth should be provided with opportunities and appropriate structure to thrive.

Program Structures

The structure of programs is very important for an effective child and youth development. An orderly learning environment is necessary for children and youth to develop positively [41]. Structure helps with categorizing program elements and practices [7]. A sequenced, active, focused, explicit (SAFE) program is the best predictor of positive effects on youth developmental outcomes [107]. Greater structure leads to higher quality implementation [85]. The greater the structure, the greater is youths' life satisfaction [108]. However, program activities should be broken down into manageable, age-appropriate, and varied blocks of instruction [85]. Appropriate structure supports skill-building 
activities, positive relationship development, and a sense of belonging, which result in the development of the six Cs of positive youth development-- competence, connection, confidence, character, caring, and contribution [109-111].

Staff youth ratio may vary from program to program. However, research suggests one adult to four young people as staff-ratio average for any program [110]. A reasonable staff ratio can foster high quality adult-youth and peer relationships. Appropriate staff ratio gives youth a chance to receive appropriate attention-frequent and in-depth interactions, which are the basis of positive youth development [107].

The program size can also potentially influence youth's behaviors in youth development programs [84]. No specific size has, however, been found in the literature. Research has suggested that program size be kept as small as possible [112]. Small program size is essential for program effectiveness [113]. In fact, young people who engage in structured activities achieve better outcomes than in unstructured activities [114].

\subsection{Social Ecological Theory}

The fourth component of the staff training model is social ecological theory. The latter emphasizes the importance of interactions between youths and the real world. The lives of adolescents and children are tied with diverse peer groups including friends, classmates, siblings, and neighborhood children [115]. Their interactions occur across different social domains as they learn and grow. These social domains or systems are classified into mesosystem, exosystem, and chronosystem [116]. The latter are respectively defined as family's environment, outside of home environment, and the physiological changes that occur within individuals over time as they grow [116].

However, youth need to have abilities and adequate skills to navigate through these diverse social systems. They must learn how to develop and sustain positive and supportive relationships with people from different social ecological learning environments. They need to develop skills, competencies, moral beliefs, and self-confidence in order to become active participants in the modern culture [117]. They need to be able to "work within social networks, pool knowledge within a collective intelligence, negotiate across cultural differences that shape the governing assumptions in different communities, and reconcile conflicting bits of data to form a coherent picture of the world around them" $[117, p$. 20]. These skills are necessary for youth to "participate fully in public, community, and economic life" [118, p. 9].

Therefore, youth workers need to understand relationships between individuals and settings [119]. Youth benefit from meaningful interactions. They experience a sense of growth and progress in developing skills and abilities when offered opportunities for meaningful interactions across the social systems [120].

Research has documented the importance of regulating the reciprocal relations between people and their diverse social environment to capitalize on youth's potential for systematic change-- plasticity. The latter can be achieved by altering individual-ecology relationships [83]. These relationships must be mutually advantageous for adaptive developmental regulations to emerge or occur [83]. These mutually advantageous relationships are the premise for a promising future distinguished by "positive contributions to self, family, community," and the society as a whole [83, p. 12].

In addition, youth developmental work should focus on improving the "fit between the capacities of youth and the assets" for healthy, thriving development that exist in their diverse social ecologies [83, p. 15]. The potential for healthy, thriving development among youth can also be achieved by aligning their strengths with resources for positive development available in their divergent social ecologies, with the assumption that youth-asset relations can be shaped in distinct and yet successful ways by divergent youth and community contexts [83].

\section{Conclusions}

There was evidence in the literature that supports the needs for staff training of youth development professionals in quality programming in order to improve youth outcomes. The literature has shown that some researchers have found that staff training correlates with program quality. Many agree that staff training is needed to improve understanding of program quality and experience in implementation practices. Well trained staff are among the key predictors of sustainable program quality. However, few agree upon which competences that are needed to implement and sustain program quality. Given the findings of this study, four areas of competence were identified: child and youth development, social ecological theory, program management, and program theory, as critical components for staff training of youth development professionals in the delivery of sustainable program quality.

\section{Recommendations}

The researchers recommend more studies on program quality in the field of positive youth development. These studies may focus on determining a common definition of program quality, its features and core practices. Further studies are also recommended to further study competencies that youth development professionals need to achieve program quality. Additionally, more studies are needed to research the relationships between staff training and program quality. Given the results of this study, the researchers propose the following model of staff training for program quality that can be used for both research and professional development purposes. From a research perspective, this staff training model should be studied to verify its structural validity. From a practice standpoint, it should be examined in terms of its real world applications (e.g., training design, cost effectiveness). 


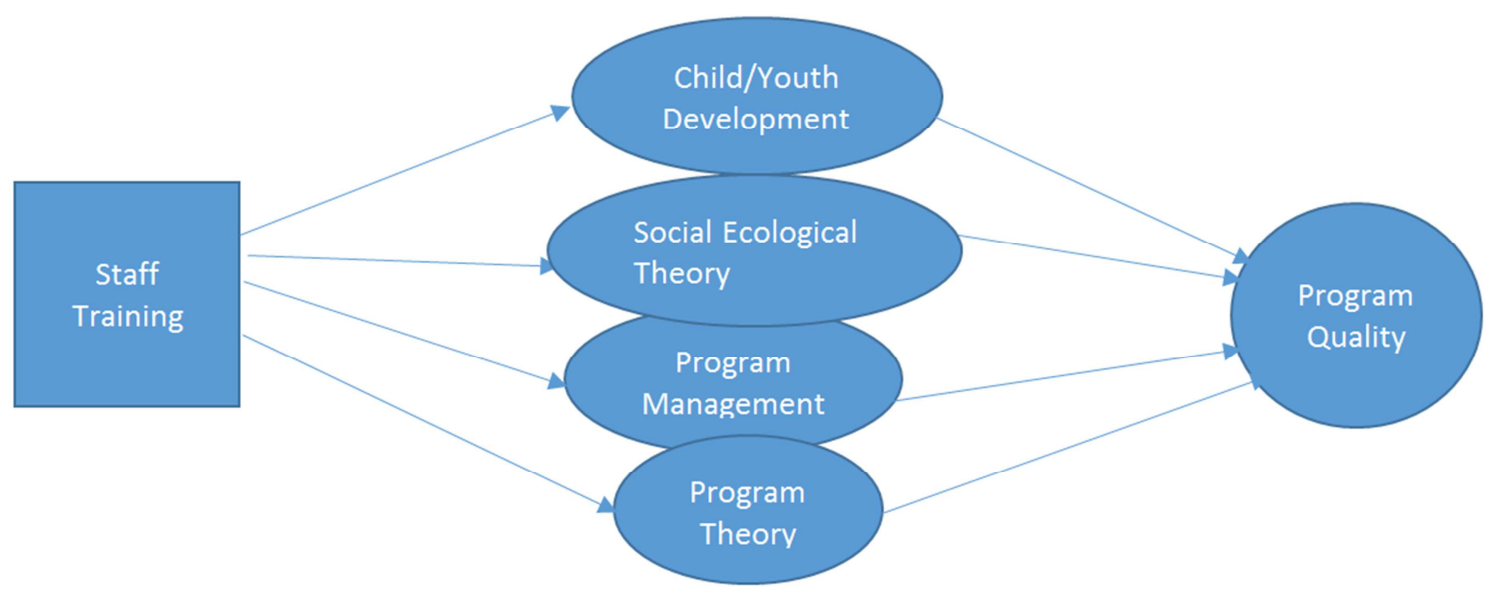

Figure 1. Norze-Cater Staff Training Model of Youth Development Program Quality.

\section{Implications}

The use of the newly developed model may enhance the preparation of youth development professionals in quality programming. Many staff who enter the field of positive youth development have knowledge deficit in quality programming. Inadequate staff preparation can lead to burnout and poor job performance, which ultimately affect program outcomes. This model may be used to improve the outcomes of positive youth development programs including afterschool and communitybased programs and camps for youth, and at the same time facilitate their evaluation. This model can also be used to guide research and future staff training and development for youth development professionals in the area of quality programming. As can be seen, program quality is relatively new to many practitioners and researchers in the field of positive youth development. This model should help with further discussions among researchers and practitioners in the arena. Furthermore, the model can be used by officials to enforce policies that support program quality. Stakeholders such as parents and elected officials are interested in the future or quality of the development of the children and youth. They may demand or enforce policies that foster healthy development of children and youth. The investment in youth is made possible through a combination of highly competitive federal, state, and local grants foundations, private donations, community organizations, and families.

\section{References}

[1] Arnold, M. E. (2015). Connecting the dots: Improving Extension program planning with program umbrella models. Journal of Human Sciences and Extension, 3 (2), 48-67.

[2] Workman, J. D., \& Scheer, S. D. (2012). Evidence of impact: Examination of evaluation studies published in the Journal of Extension [Online]. Journal of Extension, 50 (2), Article 2FEA1. Retrieved from http://www.joe.org/joe/2012april/pdf/JOE_v50_2a1.pdf.

[3] Smith, C., Akiva, T., Sugar, S., Lo, Y. J., Frank, K. A., Peck, S. C., Cortina, K. S., \& Devaney, T. (2012). Continuous quality improvement in afterschool settings: Impact findings from the Youth Program Quality Intervention study. Washington, DC: The Forum For Youth Investment. Retrieved from Http://www.cypq.org/content/continous-qualityimprovement-afterschool-settings-impact-findingss-youthprogram-quality-in.

[4] Evans, D. (1996). A stakeholder analysis of developments at the primary and secondary care interface. British Journal of General Practice, 46 (412), 675-7.

[5] Norze, J. (2018). "Building Program Quality in Youth Development Staff Training: Critical Components as Perceived by Currently Employed Youth Development Professionals in the United States". LSU Doctoral Dissertations. 4634. https://digitalcommons.lsu.edu/gradschool_dissertations/4634.

[6] Skaff, M. M., Chesla, C. A., Mycue, V. D., \& Fisher, L. (2002). Lessons in cultural competence: Adapting research methodology for Latino participants. Journal of Community Psychology, 30, 305-323.

[7] Pierce, K. M.; Bolt, D. M.; \&Vandell, D. L. (2010). Specific features of after-school program quality: Associations with Children's Functioning in Middle Childhood. $\mathrm{Am} J$ Community Psychol, 45, 381-393.

[8] Riggs, N. R, Bohnert, A. M., Guzman, M. D., \& Davidson, D. (2010). Examining the potential of community-based afterschool programs for Latino youth. American Journal of Community Psychology.

[9] Eccles, J. S., Midgley, C., Wigfield, A., Buchanan, C. M., Reuman, D., Flanagan, C., et al. (1993). Development during adolescence: The impact of stage-environment fit on adolescents' experiences in schools and families. American Psychologist, 48, 90-101.

[10] Hirsch, B. J., Mekinda, M. A. and Stawicki, J. A. (2010, March). More than attendance: The importance of after-school program quality. American Journal of Community Psychology, 45 (3-4), 447-452.

[11] Meyers, J., \& Kyle, J. E. (1996). Critical needs, critical choices: A survey on children and families in America's cities. A Research Report of the National League of Cities. Washington, DC: National League of Cities.

[12] Woodhead, M. (1996) In Search of the Rainbow: Pathways to Quality in Large-Scale Programmes for Young Disadvantaged Children. The Hague: Bernard van Leer Foundation. 
[13] Larson, R. W., \& Walker, K. C. (2010). Dilemmas of practice: Challenges to program quality encountered by youth program leaders. Am J Community Psychol, 45, 338-349.

[14] Pozzoboni, K. M., \& Kirshner, B. (Eds.) (2016). The changing landscape of youth work: Theory and practice for an evolving field. Charlotte, NC: Information Age Publishing, Inc.

[15] Cross, A. B., Gottfredson, D. C., Wilson, D. M., Rorie, M., \& Connell, N. (2010). Implementation quality and positive experiences in after-school programs. American Journal of Community Psychology.

[16] Cooper, A. W., \& Graham, D. L. (2001). Competencies needed to be successful county agents and county supervisors. Journal of Extension [On-line], 39 (1). Retrieved from: http://www.joe.org/joe/2001 february/rb3.html.

[17] Baldwin, C., \& Wilder, Q. (2014). Inside quality: Examination of quality improvement processes in afterschool youth programs. Child and Youth Services, 35, 152-168. doi: 10.1080/0145935X.2014.924346.

[18] Jucious, M. J. (1963). Personnel management (5th ed.). Homewood, IL: Richard D. Irwin.

[19] DeSario, J. P., Faerman, S. R., and Slack, J. D. (1994). Local Government Information and Training Needs in the $21 \mathrm{st}$ Centugy. Westport, CT: Quorum Books.

[20] Halim, A. and Ali, Md. M. (2005) Training and professional development. Daya Publishing House, (Ed.): Improving agricultural extension. Retrieved from: http://www.fao.org/docrep/W5830E/w5830e0h.htm\#TopOfPa ge.

[21] Olaniyan, D. A. \& Ojo. L. B. (2008). Staff Training and development: A Vital tool for organisational effectiveness. European Journal of Scientific Research, 24 (3), 326-331. ISSN 1450-216X.

[22] Oribabor, P. E. (2000), "Human Resources management, a strategic approval."Human Resources Management 9 (4), 2124.

[23] Isyaku, I. A. (2000) Training and retraining of Teachers through Distance Education. Being a paper presented at the National Workshop on Distance Education Held at Abuja Nigeria. 27-29.

[24] Orokov, B., Durning, D., pushkarev, S. (2006). Employee training and development in kyrgyzstan: leninskoye village government.

[25] Miller, B. (2005). Pathways to success for youth: What counts in after-school. Massachusetts afterschool research study. Boston, Mass.: United Way of Massachusetts Bay.

[26] Fixsen, D. L., Naoom, S. F., Blasé, K. A., Friedman, R. M., \& Wallace, F. (2005). Implementation research: A synthesis of the literature. Tampa, FL: University of South Florida, Louis de la Parte Florida Mental Health Institute, The National Implementation Research Network (FMHI Publication \#231). Retrieved from http://nirn.fmhi.usf.edu/resources/publications/Monograph/pdf/mon ograph_full.pdf.

[27] Huebner, A. J., Walker, J. A., \& McFarland, M. (2003). Staff development for the youth development professional: A critical framework for understanding the work. Youth \& Society, 35 (2), 204-225.
[28] Hall, G., Yohalem, N., Tolman, J., \& Wilson, A. (2003). How after-school programs can most effectively promote positive youth development as a support to academic achievement. Wellesley, MA7 National Institute on Out-of-School Time, Wellesley Centers for Women.

[29] Weissberg, R. P., \& O'Brien, M. U. (2004). What Works in School-Based Social and Emotional Learning Programs for Positive Youth Development. AAPSS, 591.

[30] Bowie, L., \& Bronte-Tinkew, J. (2006, December). The importance of professional development for youth workers. Child Trends. Publication 2006-17.

[31] Dall'Alba, G., \& Sandberg, J. (2006). Unveiling professional development: A critical review of stage models. Review of Educational Research, 76, 383-412.

[32] Weiss, H. B., Kreider, H., Lopez, M. E., \& Chatman, C. M. (Eds.). (2005). Preparing educators to involve families: From theory to practice. Thousand Oaks, California: Sage.

[33] Imam, U. F. (1999). Youth workers as mediators and interpreters: Ethical issues in work with black young people. In S. Banks (Ed.), Ethical issues in youth work (pp. 125-144). London, England: Rutledge.

[34] Schwandt, T. A. (2003). Back to the rough ground: Beyond theory to practice in evaluation. Evaluation, 9, 353-364.

[35] Donavant, B. (2009). The new, modern practice of adult education: Online instruction in a continuing professional education setting. Adult Education Quarterly, 59 (3), $227-$ 245 .

[36] Gallucci, C., Van Lare, M. D., Yoon, I. H., \& Boatright, B. (2010). Instructional Coaching: Building Theory About the Role and Organizational Support for Professional Learning. American Educational Research Journal, 47 (4), 919-963.

[37] Kasworm, C., Rose, A., \& Ross-Gordon, J. (2010). Handbook of adult and continuing education. Thousand Oaks, CA: Sage.

[38] Seevers, B., Conklin, N. \& Graham, D. (2007). Education through Cooperative Extension (2nd ed.). Columbus, OH: Ohio State University.

[39] Collins, M. E., Hill, N., Miranda, C. (2008). Establishing positive youth development Approaches in Group Home Settings: Training Implementation and Evaluation. Child and Adolescent Social Work Journal, 25 (1), 43-54.

[40] Yohalem N., \& Wilson-Ahlstrom, A. (2010). Inside the black box: Assessing and improving quality in youth programs. American Journal of Community Psychology; 45, 350-357. [PubMed: 20300822].

[41] Eccles, J., \& Gootman, J. A. (Eds). (2002). Community programs to promote youth development. Washington, DC: National Academy Press.

[42] Rhodes, J. (2004). The critical ingredient: Caring youth-staff relationships in after-school settings. In G. G. Noam (Ed.), After-school worlds: Creating a new social space for development and learning (New Directions for Youth Development, 101, 145-161. New York: Wiley.

[43] Durlak, J. A. (2013). The Importance of Quality Implementation for Research, Practice, and Policy. ASPE Research Brief. Retrieved from https://files.eric.ed.gov/fulltext/ED541356.pdf. 
[44] National Research Council and Institute of Medicine. (2002). Community programs to promote youth development. Committee on Community Level Programs for Youth. Jacquelynne Eccles and Jennifer A. Gootman, eds. Board on Children, Youth and Families, Division of Behavioral and Social-Sciences and Education. Washington D. C: National Academies Press.

[45] Scott, S. (2010). National dissemination of effective parenting programs to improve child outcomes. British Journal of Psychiatry, 196, 1-3.

[46] Lerner, R. M., \& Benson, P. I. (2003). Developmental assets and asset-building communities: Implications for research, policy, and practice. New York: Kluwer Academic/Plenum.

[47] Pittman, K., \& Irby, M. (1996). Preventing Problems or Promoting Development: Competing Priorities or Inseparable Goals? Baltimore: International Youth Foundation.

[48] Vance, F. (2010). A Comparative Analysis of Competency Frameworks for Youth Workers in the Out-of-School Time Field. Child and Youth Forum, 39 (6), 421-441.

[49] Keller, T. E. (2007). Program staff in youth mentoring programs: Qualifications, training, and retention. In Jean Rhodes (Ed.), Research in Action. Alexandria, VA: MENTOR/National Mentoring Partnership.

[50] Lobley, J. \& Ouellette, K. L. (2013). Maine 4-H Afterschool Academy-A Professional development opportunity for outof-school-time providers. Journal of Extension, 51 (3), Article \# 3TOT6.

[51] Borden, L. (2002). Education youth development professionals, future potential (pp. 1-12). Tucson: Institute for Children, Youth, \& Families, University of Arizona.

[52] Bednar, S. G. (2003). Elements of Satisfying Organizational Climates in Child Welfare Agencies. Families in Society: The Journal of Contemporary Human Services, 83 (1).

[53] Light, G. (2003). Realizing academic development: A model for embedding research practice in the practice of teaching. In H. Eggins \& R. Macdonald (Eds), The scholarship of academic development. Buckingam, UK: Society for Research into Higher Education \& Open University Press.

[54] Astroth, K. A., Garza, P., \& Taylor, B. (2004). Getting down to Business: Defining competencies for entry-level youth workers. New directions for youth development, 104, 25-37.

[55] Thomas, D. C. (2002). The North American certification project in historical perspective. Journal of Child and Youth Care Work, 17, 7-15.

[56] Walker, J. (2003). The essential youth worker. In F. A. Villarruel, D. F. Perkins, L. M. Borden, \& J. G. Keith (Eds.), Community youth development: Programs, policies, and practices (pp. 373-393). Thousand Oaks, CA: Sage.

[57] Hartje, J. A., Evan, W. P., Killian, E. S., \& Brown, R. (2008). Youth worker characteristics and self-reported competency as predictors of intent to continue working with youth. Child Youth Care Forum, 37, 27-41.

[58] Grossman, J. B., Price, M., Fellerath, V., Jucovy, L., Kotloff, J., Raley, R., \& Walker, K. (2002). Multiple choices after school: Findings from the Extended-Service School Initiative. Philadelphia: Public/Private Ventures.
[59] Rosenthal, R., Vandell, D. (1996). Quality of care at schoolaged child-care programs: Regulatable features, observed experiences, child perspectives, and parent perspectives. Child Development, 67, 2434-2445.

[60] Camino, L. (2005). Pitfalls and promising practices of youthadult partnerships: An evaluator's reflections. Journal of Community Psychology, 33 (1), 75-85.

[61] Stone, B. \& Rennekamp, R. (2004). New foundations for the 4-H youth development profession: 4-H professional research, knowledge, and competencies study. Conducted in cooperation with the National 4-H Professional Development Task Force. Chevy Chase, MD: National 4-H Headquarters, CSREES, USDA.

[62] Starr, E., Yohalem, N., \& Gannett, E. (2009). Youth work core competencies: A review of existing frameworks (commissioned by School's Out Washington). Seattle: Next Generation Youth Work Coalition.

[63] Diem, K. G. (2009). Preparing Youth Development Professionals to Be Successful: How Do the Needs of Extension/4-H Compare to Those of Other Organizations? Journal of Extension, 47 (1).

[64] The National Collaborative on Workforce and Disabilities (NCWD) for Youth. (2011). Core Competencies for Youth Service Professionals: Guiding Youth Toward Employment. InfoBrief, 30. Retrieved from: http://www.ncwd-youth.info/wpcontent/uploads/2016/08/Core-Competencies-for-YSPGuiding-Youth-Toward-Employ.pdf.

[65] Fordney, S. J., \& Jones, R. M. (1990). Training teachers for substance abuse prevention. In Watson, R. R. (Ed.), Drug and alcohol abuse prevention (pp. 363-372). Totowa, NJ, US: Humana Press.

[66] Sinclair, C., Dowson, M., \& McInerney, D. M. (2006). Motivations to Teach: Psychometric Perspectives Across the First Semester of Teacher Education. Teachers College Record, 108 (6), 1132-1154.

[67] Shek, D. \& Wai, C. (2008). Training workers implementing adolescent prevention and positive youth development programs: What have we learned from the literature? Adolescence, 43, 823-45.

[68] Kealey, K. A., Peterson, A. V., Gaul, M. A., Dinh, K. T. (2000). Teacher Training as a Behavior Change Process: Principles and Results from a Longitudinal Study. Health Education \& Behavior, 27 (1): 64-81.

[69] Stein, M. K. \& Wang, M. C. (1988). Teacher development and school improvement: the process of teacher change. Teaching and Teacher Education, 4 (2), 171-187.

[70] Turner, K. M. T., Nicholson, J. M., \& Sanders, M. R. (2011). The Role of Practitioner Self-Efficacy, Training, Program and Workplace Factors on the Implementation of an EvidenceBased Parenting Intervention in Primary Care. The Journal of Primary Prevention, 32 (2), 95-112.

[71] Herzog, R. J. (2004). Teaching What You Practice: The Need for Self-Reflection in Academic Settings. Journal of Public Affairs Education, $10 \quad$ (3), 225-232, DOI: $10.1080 / 15236803.2004 .12001361$

[72] Larrivee, B. (2000). Transforming teaching practice: becoming the critically reflective teacher, Reflective Practice, 1 (3), 293-307. 
[73] Orpinas, P., \& Horne, A. M. (2004). A teacher-focused approach to prevent and reduce students' aggressive behavior: The GREAT Teacher Program. American Journal of Preventive Medicine, 26 (1), 29-38.

[74] Robertson, R. J. (1997). Walking the talk: Organizational Modeling and Commitment to Youth and Staff Development. Child Welfare, 76 (5), 577.

[75] Garst, B. A., Baughman, S., \& Franz, N. K. (2013). Benchmarking Professional Development Practices across Youth-Serving Organizations: Implications for Extension. Journal of Extension, 52 (5).

[76] Bonk, C. J., \& Smith, G. S. (1998). Alternative instructional strategies for creative and critical thinking in the accounting curriculum. Journal of Accounting Education, 16 (2), 261293

[77] National Collaboration for Youth. (2004). Youth development worker competencies. Retrieved from http://www.nydic.org/nydic/staffing/profdevelopment.htm.

[78] Dennehy, J., Gannett, E., \& Robbins, R. (2006). Setting the stage for a youth development associate credential: A national review of professional development credentials for the out-ofschool time workforce. Wellesley, MA: National Institute on Out-of-School Time.

[79] Center for School and Community Services, Academy for Educational Development. (2002). BEST strengthens youth worker practice: An evaluation of building exemplary systems for training youth workers. New York: Author. Retrieved from scs.aed.org/publications/best.pdf.

[80] Freeman, J., Dorph, R., \& Chi, B. (2009). Strengthening afterschool STEM staff development. A study commissioned by the Coalition for Science Afterschool, Lawrence Hall of Science, University of California, Berkeley. Berkeley, California.

[81] Kysh, L. (2013): Difference between a systematic review and a literature review. Retrieved from https://doi.org/10.6084/m9.figshare.766364.v1).

[82] Bohnert, A., Fredricks, J., \& Randall, E. (2010). Capturing unique dimensions of youth organized activity involvement: Theoretical and methodological considerations. Review of Educational Research Season, 20 (10).

[83] Lerner, R. M., Almerigi, J. B., Theokas, C., \& Lerner, J. V. (2005).) Positive youth development: A view of the Issues. Journal of Early Adolescence, 25 (1), 10-16.

[84] Rorie, M., Gottfredson, D. C., Cross, A., Wilson, D., Connell, N. M. (2010). Structure and deviancy training in after-school programs. Journal of Adolescence 34 (2011), 105-117.

[85] Walker, K. C., \& Larson, R. W. (2006). Balancing the professional and the personal. In D. A. Blyth \& J. A. Walker (Eds.), New directions for youth development: Exceptional learning experiences for the middle years: Where high quality programs meet basic youth needs. no. 112 (pp. 109-118). San Francisco: Jossey-Bass.

[86] Almquist, P., Brekke, B., Croymans, S. R., Fruechte, K., Matlack, M., McAndrews, B., ... Zurcher, T. (2016). Keys to Quality Youth Development. Retrieved from www.extension.umn.edu.

[87] McLaughlin, M. (2000). Community counts: How youth organizations matter for youth development. Washington, DC: Public Education Network.

[88] Fagan, A. A.; Hanson, K., Hawkins, J. D., Arthur, M. W. (2008). Implementing effective community-based prevention programs in the community youth development study. Youth Violence and Juvenile Justice, 6 (3), 256-278.

[89] Carroll, C., Patterson, M., Wood, S., Booth, A., Rick, J., \& Balain, S. (2007). A conceptual framework for implementation fidelity. Implementation Science, 2, Article 40.

[90] Brophy, J. (1985). Classroom management as instruction: Socializing self-guidance in students. Theory Into Practice. Teaching Self-Discipline, 24 (4), 233-240.

[91] Rogers, P. J. (2000). Program theory: Not whether programs work but how they work. In D. L. Stufflebeam, G. F. Madaus, \& T. Kellaghan (Eds.), Evaluation models (pp. 209-232). Boston: Kluwer Academic.

[92] Weiss, C. H. (2000). Which links in which theories shall we evaluate? In P. J. Rogers, T. A. Hacsi, A. Petrosino, \& T. A. Huebner (Eds.), Program theory In evaluation: Challenges and opportunities (pp. 35-45). San Francisco, CA: JosseyBass.

[93] Arnold, M. E. \& Cater, M. (2016). Program Theory and Quality Matter: Changing the Course of Extension Program Evaluation. Journal of Extension, 54 (1).

[94] Dusenbury, L., Brannigan, R., Falco, M., \& Hansen, W. B. (2003). A review of research on fidelity of implementation: Implications for drug abuse prevention in school settings. Health Education Research, 18 (2), 237-256.

[95] Mihalic, S., Fagan, A., \& Argamaso, S. (2008). Implementing the life skills training drug prevention program: Factors related to implementation fidelity. Implementation Science, 3, Article 5.

[96] Mihalic, S. (2002). The importance of implementation fidelity. Unpublished manuscript.

[97] Chen, H. (1990). Issues in constructing program theory. New Directions for Program Evaluation, 47, 7-18.

[98] Lipsey, M. W. (1990). Design sensitivity. Newbury park, Ca: Sage.

[99] Kaftarian, S., Robertson, E., Compton, W., Davis, Beverly W., \& Volkow, N. (2004). Blending Prevention Research and Practice in Schools: Critical Issues and Suggestions. Prevention Science, 5 (1), 1-3.

[100] Durlak, J. A., \& DuPre, E. P. (2008). Implementation matters: A review of research on the influence of implementation on program outcomes and the factors affecting implementation. American Journal of Community Psychology, 41, 327-350.

[101] Gutman, L. M. \& Eccles, J. S. (2007). Stage-Environment Fit During Adolescence: Trajectories of Family Relations and Adolescent Outcomes. Developmental Psychology, 44 (2), 522-537.

[102] Meyer, D. C., Durlak, J. A. \& Wandersman, A. (2012). The quality implementation framework: a synthesis of critical steps in the implementation process. American Journal of Psychology, 50 (3-4): 462-80.

[103] Rosenbaum, D. P. (1986). Community crime prevention: Does it work? Beverly Hills, CA: Sage Publications. 
[104] Castro, F. G., Barrera, M., \& Martinez, C. R., Jr. (2004). The cultural adaptation of prevention interventions: Resolving tensions between fidelity and fit. Prevention Science, 5 (1), $41-45$.

[105] McGraw, S. A., Sellers, D. E., Stone, E. J., Bebchuk, J., Edmundson, E. W., Johnson, C. C., et al. (1996). Using process evaluation to explain outcomes: An illustration from the child and adolescent trial for cardiovascular health (CATCH). Evaluation Review, 20 (3), 291-312.

[106] Berkel, C., Mauricio, A. M., Schoenfelder, E., \& Sandler, I. N. (2011). Putting the pieces together: An integrated model of program implementation. Prevention Science, 12 (1), 23-33.

[107] Granger, R. C. (2010). Understanding and Improving the Effectiveness of After-School Practice. Am J Community Psychol, 45, 441-446.

[108] Gilman, R. (2001). The relationship between life satisfaction, social interest, and frequency of extracurricular activities among adolescent student. Journal of Youth and Adolescence, $30,749-767$.

[109] Blum, R. W. (2003). Positive youth development: A strategy for improving health. In F. Jacobs, D. Wertlieb, \& R. M. Lerner (Vol. Eds.), Enhancing the life chances of youth and families: Public service systems and public policy perspectives: Vol. 2. Handbook of applied developmental science: Promoting positive child, adolescent, and family development through research, policies, and programs ( $\mathrm{pp}$. 237-252). Thousand Oaks, CA: Sage.

[110] Henderson, K. A., Bialeschki, M. D., Scanlin, M. M., Thurber, C., Whitaker, L. S., \& Marsh, P. E. (2007). Components of camp experiences for positive youth development. Journal of Youth Development, 1 (3).

[111] Roth, J. \& Brooks-Gunn, J. (2003). What exactly is a youth development program? Answers from research and practice. Journal of Applied Development Science, 7, 94-111.

[112] Hellison, D. R. \& Cutforth, N. J. (1997). Extended day programs for urban children and youth: from theory to practice, in: H. Walberg, O. Reyes \& R. Weissberg (Eds) Children and youth: interdisciplinary perspectives (San Francisco, CA, Jossey-Bass), 223-249.

[113] Powell, D. E. (2003, summer). Demystifying alternative education: Considering what really works. Reclaiming children and youth; The Journal of Strength-based Interventions, 12 (2), 68-70.

[114] Mahoney, J., Larson, R., Eccles, J., \& Lord, H. (2005). Organized activities as development contexts for children and adolescents. In J. Mahoney, R. Larson, \& J. Eccles (Eds.), Organized activities as contexts of development: Extracurricular activities, after-school and community programs (pp. 3-22). Mahwah, NJ: Lawrence Erlbaum.

[115] Guerra, N. G., \& Bradshaw, C. P. (2008). Linking the prevention of problem behaviors and positive youth development: Core competencies for positive youth development and risk prevention. In N. G. Guerra \& C. P. Bradshaw (Eds.), Core competencies to prevent problem behaviors and promote positive youth development. New Directions for Child and Adolescent Development, 122, 1-17.

[116] Bronfenbrenner, U. (1986). Ecology of the family as a context for human development: Research Perspectives. Developmental Psychology, 22 (6), 723-742.

[117] The McArthur Foundation (2005). Confronting the challenges of participatory culture: media education for the $21^{\text {st }}$ century. South Dearborn St, Chicago, Illinois 60603.

[118] New London Group (2000). "A Pedagogy of multiliteracies: Designing social futures," in multiliteracies: Literacy learning and the design of social futures, ed. B. Cope \& M. Kalantzis for the New London Group. London: Routledge, pp. 9-38.

[119] Foucault, M. (1970). The order of things: An archaeology of the human sciences. London: Tavistock.

[120] Connell, J. P., Gambone, M. A., and Smith, T. (2000). Youth development in community settings. In Public/Private Ventures (Ed.), Youth development: Issues, challenges and directions. Philadelphia: Public/Private Ventures. 